\title{
Creation of information base of boars of Myrgorod breed, which cryopreserved sperm is stored in the bank of animal genetic resources
}

\author{
Voitenko S. ${ }^{1}$, Sydorenko O. ${ }^{2}$ \\ Institute of Animal Breeding and Genetics named after M.V. Zubets of NAAS, 1 Pohrebniaka Str., \\ Chubynske village, Boryspil region, Kyiv oblast, 08321, Ukraine; e-mail: 'slvoitenko@ukr.net, \\ 2sydorenkoolena@ukr.net; ORCID: '10000-0003-3530-6360, 20000-0003-2429-9361
}

Goal. To provide information about boars of Myrgorod breed, which sperm production is stored in deepchilled state in the Bank of animal genetic resources (Institute of genetics and animal breeding named after M.V. Zubets of NAAS) in the context of the formation of the structured information on animal genetic resources at the national level and possible recovery of the breed using modern methods. Methods. The study was conducted on boars of Myrgorod breed belonging to the lines Veselyi, Dnipro, Komysh, and Lovchyk. The study of immunogenetic characteristics of boars was carried out by 9 genetic systems of blood groups: EAA, $E A B, E A D, E A E, E A F, E A G, E A H, E A K$, and EAL. The processing involved data from all boars of these lines that were in the breed. Assessment of boar semen was carried out on the ejaculate volume and mobility of sperm cells in the laboratory of artificial insemination of breeding plant SE «SF named after Decembrists of the Institute of pig breeding and agro-industrial production of NAAS». They took semen from boars during the year in the mode of the sexual use - one cage in 3 days. They determined the average volume of ejaculate and motility of sperm cells. The characteristic of boars as to the productivity was made on the indicators of live weight, body length, age of reaching a live weight of $100 \mathrm{~kg}$ during growth, and multiple pregnancies in sows inseminated by them. Results. It was found that among the examined boars the most common allelic variants were A, Ba, Db, Eedg, Eaeg, Fb, Gb, H, Kb, Lb with a frequency of $0.233-1.000$. To the category of relatively rare were read alleles Eaef, Ka, Ld with a frequency of 0.033- 0.067 . The boars of Myrgorod breed did not differ significantly among themselves for the most of the genetic systems of blood groups, besides systems of EAE, EAK, and EAL. The obtained results give the possibility to realize a homogeneous or heterogeneous selection and to create desirable genotypes in the breed in case it is subjected to recovery. The largest volume of ejaculate sperm was obtained from boars of lines Veselyi and Dnipro (223.8 and $227.4 \mathrm{ml}$ respectively), the smallest - from line Komysh $(139.6 \mathrm{ml})$, which was probably due to the individual characteristics of animals and their heredity. The sperm of the studied boars were not significantly different in the mobility of sperm cells (9.0-9.5 points). Conclusions. The characteristics of the boars-manufacturers on the genetic systems of blood groups, sperm quality, and performance are given. This information can be used to retrieve ancestors of lines or families in the recovery process of the Myrgorod breed of pigs and the creation of other genotypes. It will also help to solve the complex problems of preservation and use of local endangered breeds of agricultural animals of Ukraine under the recommendations of the Commission on animal genetic resources of FAO.

Key words: boars-manufacturers, blood group, immunogenetic characteristics, sperm quality, performance.

\section{DOI: https://doi.org/10.31073/agrovisnyk202006-05}

Anthropological human activity, changes in ecosystems, intensive use of natural and economic resources exacerbates the global problem of conservation and protection of biological diversity of animals, including agricultural. Although the awareness of the role of animal genetic resources in food supply, the formation of export-import relations and the development of the world economy is undeniable, from the map of the Earth and most countries continue to disappear farm animal species that are not attractive for intensive production them of the corresponding type of product [1-4].

Preserving their unique gene pool in the form of live animals kept in gene pool, relict herds, collectibles and other objects is not always possible given the breeding of animals in small closed populations, where sooner or later there will be inbreeding depression and local degeneration. individuals. In addition, another factor that destroys populations should not be neglected - it is a different kind of disease.

To avoid the fatal effects of various factors and to preserve animal biodiversity, the International Food Organization (FAO) has recommended that animal genetic resources, other than relict or gene pool herds, be stored in long-term storage banks for biological material. If the time comes when for some reason almost all members of a single population of animals disappear, the opportunity to reproduce them will not disappear due to genetic material (sperm, embryos, eggs) stored in cryobanks. In addition, the use of modern genetic technologies will allow the available material to identify animals, determine their similarity and diversity, genetic potential, marker genes, which, in turn, will confirm the feasibility of a strategy to preserve the population [5, 6]. The need to preserve genetic material in the bank of genetic resources of animals and its further use to regulate the biodiversity of wildlife is also indicated in the Program for the preservation of the gene pool of local and endangered breeds of farm animals in Ukraine [7].

One of the most practical means of storing genetic material, due to the availability of applications, is the sperm of males. Sperm stored in liquid nitrogen can restore an animal population immediately or decades or 
centuries later. Male semen can be used for artificial insemination or in vitro fertilization of females, is the basis for maintaining the existing diversity or maintaining heterozygosity in a small population of animals. It is especially important to keep male sperm in a cryopreserved state in the presence of live females, but it becomes even more important when there are no live females, but there are their eggs. As the last variant of restoration of breed the absorbing crossing with a related group or other breed is considered. However, the reconstruction of the breed by using the sperm of the offspring by absorbing crossing of the respective breed will not allow to restore all the genetic diversity of the breed. It should also be noted that short-term or longterm storage of sperm in a deep-chilled state with its subsequent use for insemination of females is effective for most species of farm animals, but problematic for pigs.

In pig breeding, methods of cryopreservation of boar sperm were tested in the middle of the last century and the era of artificial insemination of sows with frozen-thawed sperm began in different countries of the world, which gave positive results. However, cryopreserved boar semen is still problematic in terms of efficiency, despite the search for and development of methods to increase its fertility [8-12].

Despite the problem of cryopreservation of sperm in animals of the species Sus scrofa domesticus and the effectiveness of its use for insemination of sows, this method is one of the main in restoring the endangered population or preserving its gene pool. Even if the motility and viability of sperm after mating is not very high, you can still get one or two piglets for farrowing from a sow that will be artificially inseminated with this sperm and begin to restore the breed by purebred breeding.

In the last few years in Ukraine, and not only, the African plague has caused enormous damage to pig farming. Its consequences for the Myrhorod breed of pigs, which were kept in only one herd in Ukraine and were exterminated in 2018, were particularly impressive. Only a few members of this local breed survived, which can still be used to restore the breed. Despite the slightly lower productivity of Myrhorod pigs compared to modern commercial breeds, especially in terms of meat yield in the carcass, they have a number of valuable biological features: high stress resistance, ability to consume roughage and succulent feed, good digestibility of feed, adaptability to different retention technologies, significant fat content in the carcass, the formation of muscle tissue before the age of 6 months, and then - adipose tissue, high quality meat due to the presence of fat in the muscle tissue, etc. [13]. In addition, the Myrhorod pig breed, created in Ukraine, is a cultural heritage and national heritage, which encourages scientists to restore the breed using various methods, including artificial insemination of sows with cryopreserved sperm stored in the bank of animal genetic resources of the Institute of Animal Breeding and Genetics nd. a. M.V.Zubets of NAAS.

However, to use the sperm of boars of the Myrhorod breed, which is stored in a deep-cooled state in the gene pool, you need to have a complete description of the material, because it is unknown how far in the future the samples will be restored. In order for the material to be available to stakeholders at the national and international levels, the description of the genetic material should be based on the widest possible information about the donor animal, including the genetic characteristics of the individual, indicators of its development and productivity, health, etc. This approach is in line with FAO's recommendations for studying the diversity of animal genetic resources and their further use [5].

In view of this, it is important to provide comprehensive information about breeding boars of Myrhorod breed, the semen of which is stored in a deeply cooled state in the bank of animal genetic resources of the Institute of Animal Breeding and Genetics nd. a. M.V.Zubets of NAAS and which can be used to restore the breed or reproduce genotypes.

Goal. To provide information about boars of Myrgorod breed, which sperm production is stored in deepchilled state in the Bank of animal genetic resources of Institute of genetics and animal breeding named after M.V.Zubets of NAAS in the context of the formation of the structured information on animal genetic resources at the national level and possible recovery of the breedusing modern methods.

Materials and methods of research. The object of research were boars of Myrgorod breed belonging to the lines Veselyi, Dnipro, Komysh, and Lovchyk. The study of immunogenetic characteristics of boars was carried out by 9 genetic systems of blood groups (EAA, EAB, EAD, EAE, EAF, EAG, EAH, EAK, and EAL) conducted in the laboratory of genetics of the Institute of Pig Breeding of NAAS. For immunogenetic testing from each animal from the vena cava in the breeding plant of SE RH "nd. a. Decembrists" of the Institute of pig breeding and agro-industrial production of NAAS» Poltava region took blood samples in labeled tubes with anticoagulant solution. To prepare the erythrocyte suspension, $3 \mathrm{ml}$ of blood was taken and transferred to labeled centrifuge tubes to which saline was added. The tubes were placed in the wells of the centrifuge rotor and centrifuged for 10 minutes at a speed of $3000 \mathrm{rpm}$. After that, the supernatant was aspirated from the tubes with a water jet pump and to obtain a clean supernatant it was washed three times with saline. A $2,5 \%$ suspension was made from washed erythrocytes in physiological saline. Monospecific serum reagents were adjusted to operating concentration by dilution with saline, taking into account serum titer and number of blood samples, before performing the agglutination reaction. To determine the agglutination reaction, a serological plate was used, which was signed according to the animal information form. Appropriate reagent and suspensions of boar erythrocytes were introduced into the wells of the plate using droppers, the tablet was shaken and placed in a thermostat at a temperature of $27{ }^{\circ} \mathrm{C}$ for 2 hours. After that, the first reading of the reaction was performed and the tablet was again placed in the thermostat for 4 hours, after which the final, second reading of the reaction was performed. The degree of reaction of agglutination and hemolysis was evaluated on a 4-point scale. The frequencies of alleles for closed, open and complex genetic systems of blood groups were determined using appropriate formulas [14]. Immunogenetic characteristics of the lines were made according to 7 boars of the line Veselyi's, 6 boars of the line Dnipro's, 9 boars of the line Komysh's and 7 boars of the line Lovchyk's, ie all available boars that were in the breed. 
Assessment of boar semen was carried out on the ejaculate volume and mobility of sperm cells in the laboratory of artificial insemination of breeding plant SE «SF nd. a. Decembrists of the Institute of pig breeding and agroindustrial production of NAAS». Experimental boars lines Veselyi, Dnipro, Komysh and Lovchyk of 3 heads from each line, including animals from which semen was selected for cryopreservation, were analogous in age and kept in the same conditions. Assessment of sperm quality began when the animals reached 12 months of age and ended when they reached the age of 24 months. They took semen from boars during the year in the mode of the sexual use - one cage in 3 days. Boar semen was obtained using a stuffed animal and an artificial vagina. Sperm quality was determined visually by color and odor, as well as volume and motility. Ejaculate volume was determined by weighing on electronic scales. Sperm motility was determined using a microscope at a magnification of 300 times on a table Morozova at a temperature of $380 \mathrm{C}$ on a tenpoint scale. To determine the averages for each boar, the ejaculate volumes obtained during the year were added and divided by the number of cages. CRONOS diluent was used to dilute and store sperm in such a way that $1 \mathrm{ml}$ contained 40-50 million biologically complete sperm. The resulting semen was packaged in vials of $90 \mathrm{ml}$ each. Specially equipped thermoses in which the temperature was maintained at the level of 16-20 ${ }^{\circ} \mathrm{C}$ were used to transport the sperm of Myrhorod boars to the bank of animal genetic resources of the Institute of Animal Breeding and Genetics named after M.V. Zubets of NAAS. For long-term storage, boar semen was frozen in the form of granules, which were then placed in tubes in a Dewar vessel.

For the detailed embodiment of the genetic product of worldly boars preserved for preservation, the following connotations remained: live weight - release on birthday at 24 months, body length - the ability to save a measuring arrow coming from a useful crest to the root of the tail at 24 months, the age at which the animals reach a live weight of $100 \mathrm{~kg}$ during rearing - the difference between the date of birth and the date of achievement by the animals of a live weight of $100 \mathrm{~kg}$ per day. The study included at least 25 farrowing sows on each boar of the studied lines.

Research results. For long-term storage in the bank of animal genetic resources of the Institute of Animal Breeding and Genetics of NAAS NAAS sperm of 6 purebred boars of Myrhorod breed lines Dnipro, Veselyi, Komysh and Lovchyk were imported from SE «SF nd. a. Decembrists» and SE «Experimental base «Nadiya» of the Institute of Pig Breeding and Agro-industrial production of NAAS. Boar semen is stored in tubes, which are placed in Dewar vessels filled with liquid nitrogen. An average of 250 sperm granules are stored from each of the 6 boars, ie a "virtual herd" of Myrhorod pigs has been created in this bank of animal genetic resources. It consists of cryopreserved sperm of known origin in an amount sufficient to reproduce a full-fledged gene pool both for use with live sows of Myrhorod breed for purebred breeding, and sows of other breeds for absorption crossing. In addition, it is possible to obtain purebred offspring by biotechnology using female eggs.

To provide the most complete information about animals, in accordance with the recommendations of FAO [5], boars of Myrhorod breed were characterized by 9 genetic systems of blood groups. The results of immunogenetic studies showed that among the boars of Myrhorod breed the most common were the following allelic variants of the corresponding blood groups: A-, Ba, Db, Eedg, Eaeg, Fb, Gb, H-, Kb and Lb (frequency of which was $0,233-1,000)$. The relatively rare alleles include Eaef, Ka, Ld alleles (table), which were found in animals of the studied lines with a frequency of 0,033-0,067. It is established that boars of Myrgorod breed did not differ significantly among themselves for the most of the genetic systems of blood groups, besides systems of EAE, EAK and EAL.

\section{Gene frequency of alleles of genetic systems of blood groups of boars of Myrhorod breed}

\begin{tabular}{|c|c|c|c|c|c|}
\hline \multirow{2}{*}{$\begin{array}{c}\text { Genetic } \\
\text { systems of } \\
\text { blood groups }\end{array}$} & \multirow{2}{*}{ Allel } & \multicolumn{4}{|c|}{ Line } \\
\hline & & Veselyi & Dnipro & Komysh & Lovchyk \\
\hline \multirow[t]{2}{*}{ EAA } & - & 0,775 & 0,764 & 0,745 & 0,745 \\
\hline & $\mathrm{cp}$ & 0,225 & 0,236 & 0,255 & 0,255 \\
\hline \multirow[t]{2}{*}{$\mathrm{EAB}$} & a & 0,800 & 0,917 & 0,833 & 0,778 \\
\hline & $\mathrm{b}$ & 0,200 & 0,083 & 0,167 & 0,222 \\
\hline \multirow[t]{2}{*}{ EAD } & $a$ & 0,167 & 0,042 & 0,056 & 0,000 \\
\hline & $b$ & 0,833 & 0,958 & 0,944 & 1,000 \\
\hline \multirow[t]{5}{*}{$\mathrm{EAE}$} & aeg & 0,233 & 0,333 & 0,389 & 0,333 \\
\hline & ebg & 0,067 & 0,000 & 0,111 & 0,056 \\
\hline & edg & 0,500 & 0,417 & 0,444 & 0,333 \\
\hline & edf & 0,167 & 0,250 & 0,056 & 0,278 \\
\hline & aef & 0,033 & 0,000 & 0,000 & 0,000 \\
\hline \multirow[t]{2}{*}{ EAF } & $a$ & 0,233 & 0,208 & 0,125 & 0,111 \\
\hline & $b$ & 0,767 & 0,792 & 0,875 & 0,889 \\
\hline \multirow[t]{2}{*}{ EAG } & $a$ & 0,333 & 0,417 & 0,389 & 0,333 \\
\hline & $b$ & 0,667 & 0,583 & 0,611 & 0,667 \\
\hline \multirow[t]{2}{*}{$\mathrm{EAH}$} & - & 0,775 & 0,764 & 0,866 & 0,816 \\
\hline & $a$ & 0,225 & 0,236 & 0,134 & 0,184 \\
\hline \multirow[t]{3}{*}{ EAK } & - & 0,512 & 0,298 & 0,315 & 0,000 \\
\hline & $a$ & 0,068 & 0,090 & 0,054 & 0,000 \\
\hline & $\mathrm{b}$ & 0,419 & 0,612 & 0,631 & 1,000 \\
\hline
\end{tabular}




\begin{tabular}{|c|c|c|c|c|c|}
\hline \multirow{3}{*}{ EAL } & ai & 0,200 & 0,167 & 0,167 & 0,056 \\
\cline { 2 - 6 } & bcgi & 0,567 & 0,792 & 0,722 & 0,889 \\
\cline { 2 - 6 } & aki & 0,167 & 0,000 & 0,056 & 0,000 \\
\cline { 2 - 6 } & d & 0,067 & 0,042 & 0,056 & 0,056 \\
\hline
\end{tabular}

According to the polymorphic genetic system of EAA blood groups, the highest frequency of the Ao allele $-0,775$ was found in boars of the line Veselyi, slightly lower - in boars of the line Dnipro -0.764 and the same frequency of the studied allele was found in boars of the lines Lovchik and Komysh $-0,745$. The frequency of the alternative allele (Acp) among animals ranged from 0,225 to 0,25 .

The diallel genetic system of blood groups B in Myrhorod breeders is represented by two codominant alleles - $\mathrm{Ba}$ and $\mathrm{Bb}$, the concentration of which differs slightly among the studied lines. In the polymorphic locus of $E A B$, the highest frequency of the Ba allele $-0,917$ was found in boars of the line Dnipro, while in animals of other lines - in the range of $0,778-0,833$.

It should be noted that among the boars of the 4 studied lines of the Myrhorod breed, the representatives of the line Lovchyk did not have the Da allele, and the boars of the lines Dnipro and Komysh had a low frequency. According to the frequency of this allele, it is possible to make assumptions about the similarity of pigs of the studied lines to Asian wild boars. The absence of the Da allele is also consistent with the high reproductive capacity of pigs, which should be taken into account when selecting animals to create the desired genotypes.

In the boars of the Veselyii line, 5 complex alleles of the genetic system of the EAE blood group were found, in the lines of Dnipro, Komysh and Lovchyk - 4. The most common in animals of these lines was the Eedg allele, the frequency of which was $0,333-0,500$. Boars of the lines Dnipro, Komysh and Lovchyk did not have the Eaef allele, while the line Dnipro did not have the Eebg allele. It is believed that the phenogroup "edg" controls the prenatal viability of pigs and the manifestation of the effect of heterosis [15] and may be a desirable marker in the selection of pigs with high viability and productivity.

The diallel genetic system of EAF blood groups in Myrhorod boars is characterized by a high frequency of the Fb allele: from 0,767 in the line Veselyi to 0.889 in the line Lovchyk, as well as by the presence of the Fa allele $(0,111-0,233)$. The latter fact suggests that boars of the studied lines, despite artificial selection, in their genotype are somewhat similar to wild boar, because most pigs do not have this allele or its frequency is quite low [15].

The importance of the genetic system of EAN blood groups lies in its connection with the productivity of pigs and, in particular, fertility, stress and meat quality. Among the studied lines of Myrhorod breed, 2 antigens were found for the preference of animals with erythrocyte antigen $\mathrm{H}$-. The concentration of erythrocyte antigen $\mathrm{H}$ - among boars of Myrhorod breed varied from 0,764 in the Dnipro line to 0,866 in the Komysh line. The low content of erythrocyte antigen $\mathrm{Na}$ in boars of the Myrhorod breed may be consistent with their belonging to the fat genotype, as meat-producing pigs must be characterized by a frequency of this allele of not less than 0,320 [15]. Taking this information into account when creating lines in the breed will make it possible to obtain animals with a higher meat content in the carcass.

Polyalelic systems of blood groups $\mathrm{K}$ and $\mathrm{L}$ have a fairly large variability of the allelofund and there is no definite pattern of their connection with the productivity of pigs. The genetic system of EAK blood groups in boars of the Veselyi, Dnipro and Komysh lines is 3 alleles with different frequency. At the same time, the Ka allele had a rather low frequency in the animals of the above lines, which makes it possible to classify it as rare for the breed. The genetic system of blood groups $L$ is one of the most complex polyalelic systems, especially in the Myrhorod breed of pigs, where the share of "imported" genotypes in the pedigrees of animals is significant. Thus, the Laki and Ld alleles are not common among Myrhorod boars, while the Lbcgi allele has a high frequency.

In general, the characterization of boars of Myrhorod breed by genetic systems of blood groups allows to expand information about the breed, helps to create the desired genotypes by homo- or heterogeneous selection of parental forms, taking into account individual alleles of genetic systems of blood groups, determining the diversity of animal genetic resources deep-chilled state.

The information base of Myrhorod boars, the semen of which is stored in the bank of animal genetic resources of the Institute of Animal Breeding and Genetics nd. a. M.V. Zubets of NAAS, outside the immunogenetic characteristics of animals, should be supplemented with indicators of their semen quality, including ejaculate volume and sperm motility. Estimation of semen of boars of the Veselyi, Dnipro, Komysh and Lovchyk lines made in the conditions SE RH «nd. a. Decembrists» of Pig Breeding and Agro-industrial production of NAAS, indicates the existence of a significant difference between the animals of the studied lines, which is probably due to their individual characteristics and heredity of traits. With the variation of sperm volume among boars of the Myrhorod breed in the range of 227,4 - $139.6 \mathrm{ml}$, the largest volume is characteristic of boars of lines Veselyi and Dnipro, respectively, 223,8 and $227.4 \mathrm{ml}$ and the smallest - from line Komysh - 13,6 ml.

The unconsolidation of the Myrhorod boar lines is also confirmed by the sperm motility indices, which were 9,5 points for the line Veselyi and 9 points for the line Komysh, although in general the sperm of all animals was of high quality (fig. 1). 


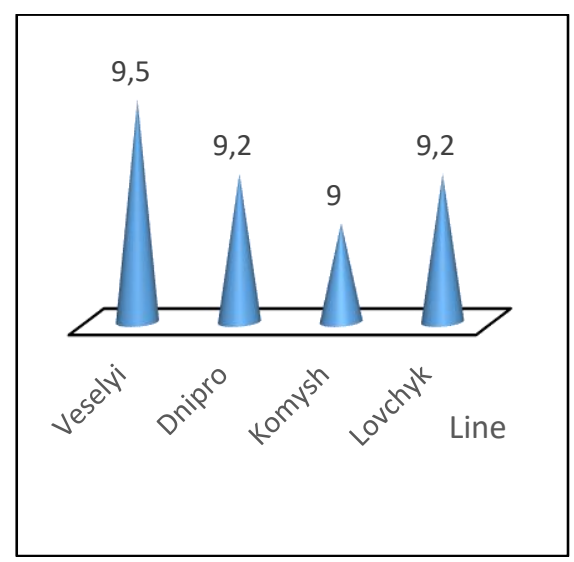

Fig. 1. Sperm motility in boars lines Veselyi, Dnipro, Komysh and Lovchyk, points

Boars of Myrhorod breed differed from each other in live weight at the age of 24 months. The most massive were the boars of the line Dnipro, whose live weight was $279 \mathrm{~kg}$ (fig. 2). Boars of other lines were inferior to the representatives of the line Dnipro in live weight by $8-11 \mathrm{~kg}$, which is probably due to the heredity of the animals and their individual characteristics, as the breeders were raised in the same conditions and level of feeding.

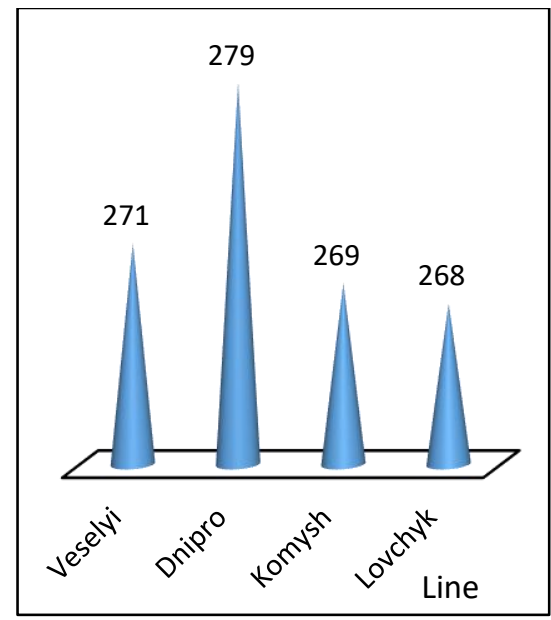

Fig. 2. Live weight of boars of the lines Veselyi, Dnipro, Komysh and Lovchyk, kg

The possibility of selection to increase the growth rate of pigs is evidenced by the age of reaching a live weight of $100 \mathrm{~kg}$ during rearing. Among the studied animals, the highest intensity of growth during rearing was the boars of the line Komysh, which reached a live weight of $100 \mathrm{~kg}$ in 195 days, the boars of the line Veselyi grew more slowly, in which the age of reaching a live weight of $100 \mathrm{~kg}$ was 217 days (Fig. 3). This information can be used in the process of breed restoration and the creation of individuals with high growth rates in purebred breeding.

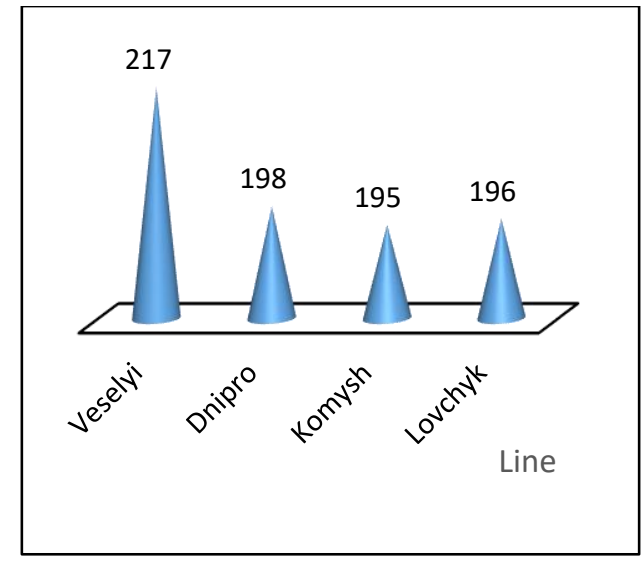

Fig. 3. Age of achievement of live weight of $100 \mathrm{~kg}$ by boars of the Veselyi, Dnipro, Komysh and Lovchyk lines, days 
One of the main indicators that affects the economic evaluation of the efficiency of the breed and confirms the level of reproductive capacity of boars is considered to be fertility, or the number of live piglets at birth. For boars, this figure is determined by the fertility of sows artificially inseminated with boar semen. Undoubtedly, the number of live piglets at birth is influenced by many genotypic and paratypic factors: breed, age of animals, heredity of the trait, compatibility of parental pairs, housing conditions, feeding level, farrowing technology and others. In general, sows of Myrhorod breed are not characterized by high fertility, primarily due to their breed characteristics, so the fertility of sows artificially inseminated with semen of boars of the studied lines were at the level of 9,5-9,9 heads (Fig. 4).

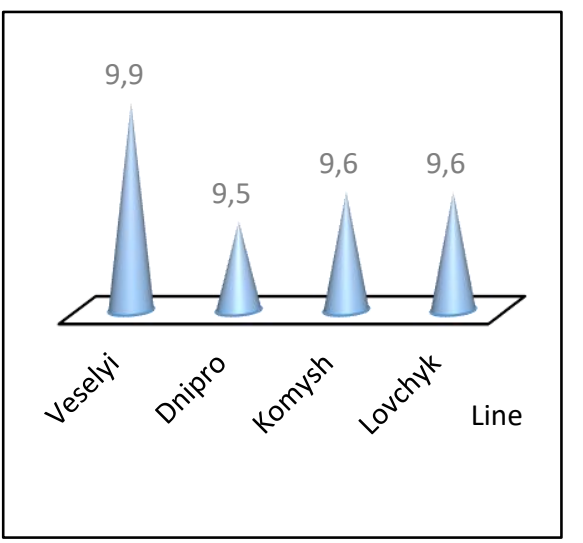

Fig. 4. Fertility of boars of the lines Veselyi, Dnipro, Komysh and Lovchyk, heads

The highest fertility - 9,9 heads of piglets per farrowing was characteristic of boars of the line Veselyi, and the lowest $-9,5$ heads - of the line Dnipro. The results of this assessment make it possible to choose the most productive line of the Myrhorod breed, although all animals should be used to restore its population and preserve genetic variability in the population.

\section{Conclusions}

According to the results of the research, the information about boars of Myrhorod breed, the semen of which is stored in a deeply cooled state in the bank of genetic resources of animals of the Institute of Animal Breeding and Genetics nd. a. M.V. NAAS tooth and can be used to obtain the ancestors of lines or families in the process of restoring the Myrhorod breed of pigs or in creating the desired genotypes. In addition, this information will help address a range of issues related to the conservation and use of local, endangered farm animal breeds in Ukraine in accordance with the recommendations of the FAO Commission on Animal Genetic Resources.

Immunogenetic characteristics of boars of the Myrhorod breed according to 9 genetic systems of blood groups showed a slight difference between animals in most genetic systems of blood groups, except for the systems EAE, EAK and EAL. The obtained information testifies to the possibility of creating a population of pigs with the desired signs of productivity due to the combination of parent pairs with the same or different complex of alleles of the studied genetic systems of blood groups.

Boars of the studied lines of Myrhorod breed were characterized by different volume of sperm ejaculate and sperm motility, which is probably due to the individual characteristics of animals, their heredity, as well as belonging to the line.

It was found that the boars of the studied lines, although raised in the same conditions, were analogous in age, but were characterized by different live weight at the age of 24 months, which should be taken into account when selecting a breeder to create a line or family in the breed. No significant effect of animal origin on body length has been established. Probably, the heredity of the ancestor of the lines has a greater impact on the live weight of animals, rather than on the length of the body. In addition, the selection of animals by body length at the level of medium breeds made it possible to create a consolidated population with little genetic variability of the trait.

Boars of the Komysh and Lovchyk lines grew the most intensively, reaching a live weight of $100 \mathrm{~kg}$ in 195 and 196 days, respectively, which should be taken into account in selection work with the breed, as well as when choosing a boar as a successor or ancestor of a new line.

The multiplicity of boars of different lines of Myrhorod breed confirms the insignificant variability of the trait and is consistent with the breed characteristics of animals. In addition, the semen of boars of the Myrhorod breed, which is stored in the sperm bank, can be used to form the genealogical structure of the breed during its recovery, as well as to maintain the biological diversity of pigs not only in Ukraine but also in the world.

\section{References}

1. Global Plan of Action for Animal Genetic Resources and the Interlaken Declaration on Animal Genetic Resources (adopted by the International Technical Conference on Animal Genetic Resources for Food and Agriculture; Interlaken, Switzerland, 3-7 September 2007). Commission on Genetic Resources for Food and Agriculture. (2008). Rome: FAO. 
2. Ulimbashev, M. B., Kulintsev, V. V., Selionova, M. I. et al. (2018). Ratsionalnoe ispolzovanie genofonda tsennykh porod zhivotnykh $s$ tselyu sokhraneniya biologicheskogo raznoobraziya [Rational use of the gene pool of valuable animal breeds in order to preserve biological diversity]. South of Russia: ecology, development, 13(2), 165-183. doi: 10.18470/1992-1098-2018-2-165-183. [In Russian].

3. Gandini, G., Ollivier, L., Danell, B. et al. (2004). Criteria to assess the degree of endangerment of livestock breeds in Europe. Livestock Production Science, 91(1-2), 173-182. doi: 10.1016/j.livprodsci.2004.08.001.

4. Tisdell, C. (2003). Socioeconomic causes of loss of animal genetic diversity: analysis and assessment. Ecological Economics, 45(3), 365-376. doi: 10.1016/S0921-8009(03)00091-0.

5. Molecular genetic characterization of animal genetic resources. FAO Animal Production and Health Guidelines. Commission on Genetic Resources for Food and Agriculture (2011). (Vol. 9). Rome: FAO of the UN.

6. Stolpovskiy, Yu. A., \& Zakharov-Gezekhus, I. A. (2017). Problema sokhraneniya genofondov domestitsirovannykh zhivotnykh [The problem of preserving the gene pools of domesticated animals]. Vavilov Journal of Genetics and Breeding, 21(4), 477-486. doi: 10.18699/VJ17. 266. [In Russian].

7. Hladii, M. V., Polupan, Yu. P., Basovskyi, D. M. et al. (2018). Prohrama zberezhennia lokalnykh ta znykaiuchykh porid silskohospodarskykh tvaryn v Ukraini na 2017-2025 roky [Program for conservation of local and endangered breeds of farm animals in Ukraine for 2017-2025]. Sumy. [In Ukrainian].

8. Silva, C. G., Cunha, E. R., Blume, G. R. et al. (2015). Cryopreservation of boar sperm comparing different cryoprotectants associated in media based on powdered coconut water, lactose and trehalose. Cryobiology, 70, 90-94. doi: 10.1016/j. cryobiol. 2015.01.001.

9. Rodriguez-Martinez, H., \& Wallgren, M. (2011). Advances in Boar Semen Cryopreservation. Veterinary Medicine International. Article ID 396181. doi: 10.4061/2011/396181.

10. Roca, J., Hernandez, M., Carvajal, G. et al. (2010). Factors influencing boar sperm cryosurvival. J. Anim Sci, 84, 2692-2699.

11. Wu, T. W., Cheng, F. P., Chen, I. H. et al. (2013). The combinatorial effect of different Equex STM paste concentrations, cryoprotectants and the straw-freezing methods on the post-thaw boar semen quality. Reprod Domest Anim, 48, 53-58. doi:10.1111/j.1439-0531.2012.02022.x.

12. Pena, F. J., Saravia, F., \& Garcia-Herreros, T. (2005). Identification of sperm morphometric subpopulations in two different portions of the boar ejaculate and its relation to postthaw quality. Andrology, 26(6), 716-723. doi: 10.2164/jandrol.05030.

13. Voytenko, S. L., Vishnevskiy, L. V., \& Petrenko, S. N. (2018). Svinovodstvo Ukrainy - etapy razvitiya, produktivnost zhivotnykh i kachestvo produktsii [Pig breeding in Ukraine - stages of development, animal productivity and product quality]. Zootehnie $i$ Biotehnologii agricole: materialele Simpozionului Stiintific International "85 ani ai Facultaii de Agronomie - realizari i perspective", dedicat aniversarii a 85 de ani de la fondarea Universitatii Agrare de Stat din Moldova. (Vol. 52(2), pp. 126-132). Chininau. [In Russian].

14. Berezovskyi, M. D., Revenko, O. I., \& Vozniuk, L. I. (2005). Metodyka imunohenetychnoho kontroliu v stadi: Suchasni metodyky doslidzhen u svynarstvi [Methods of immunogenetic control in the herd: Modern research methods in pig breeding]. Poltava. (pp. 22-25). [In Ukrainian].

15. Tikhonov, V. N. (1991). Immunogenetika i biokhimicheskiy polimorfizm domashnikh i dikikh sviney [Immunogenetics and biochemical polymorphism of domestic and wild pigs]. Novosibirsk: Science. [In Russian]. 